\title{
State policy on the formation of students' civic and social competences in conditions of educational reform
}

\author{
Valentyna Sahuichenko \\ Dnipro Academy of Continuing Education, Dnipro, Ukraine
}

Vyacheslav Shynkarenko ${ }^{\mathrm{ii}}$ iD

Dnipro Academy of Continuing Education, Dnipro, Ukraine

Ivan Bezenaiiii

Dnipro Academy of Continuing Education, Dnipro, Ukraine

Olha Perederiiivi(D)

Dnipro Academy of Continuing Education, Dnipro, Ukraine

Olha Martynenkovid

Dnipro Academy of Continuing Education, Dnipro, Ukraine

\begin{abstract}
The article emphasizes the relevance of the formation of students' civic and social competences during the reformation of educational institutions according to the concept of the New Ukrainian School with the ability to appreciate the cultural diversity of different peoples and identify themselves as citizens of Ukraine. Emphasis is placed on the results of the research and experimental work "Formation of the value-meaningful sphere of children of preschool and primary school age" on the issues of national-patriotic education. It is proposed to consider the national idea through the philosophical reflection of the educational issues in the conditions of globalization and to identify the tendencies of developing national education in response to the challenges and risks of modern society that affect the functioning of educational institutions. In order to solve theoretical issues, it is important to involve the scientific results of specialists in different directions: public administration, philosophy, pedagogy, psychology, sociology, communication theory, cultural studies, politology, national security, economy. It is determined that the reasons of insufficient level of teachers' readiness for systematic and purposeful work on patriotic upbringing of students should be sought in the incomplete use of the potential of the educational subjects, the lack of scientific and substantive methods and a set of didactic tools (textbooks, audiobooks, teaching materials) providing support in the practical acquisition of students' knowledge, skills, and creative use of them in cognitive activity.
\end{abstract}

\section{Keywords}

Education reform. National patriotic education. Public policy. Civic and social competences.

Educ. Form., Fortaleza, v. 5, n. 3, p. 1-22, set./dez. 2020

DOI: https://doi.org/10.25053/redufor.v5i15set/dez.3080

https://revistas.uece.br/index.php/redufor/index 


\title{
Política estadual de formação de competências cívicas e sociais dos estudantes em condições de reforma educacional
}

\begin{abstract}
Resumo
O artigo enfatiza a relevância da formação das competências cívicas e sociais dos estudantes durante a reforma das instituições de ensino, de acordo com o conceito da Nova Escola Ucraniana, com a capacidade de apreciar a diversidade cultural de diferentes povos e se identificar como cidadãos da Ucrânia. Ênfase é colocada nos resultados da pesquisa e trabalho experimental "Formação da esfera de valor significativo de crianças em idade pré-escolar e escolar" sobre as questões da educação nacional-patriótica. Propõe-se considerar a ideia nacional através da reflexão filosófica das questões educacionais nas condições da globalização e identificar as tendências do desenvolvimento da educação nacional em resposta aos desafios e riscos da sociedade moderna que afetam o funcionamento das instituições educacionais. Para resolver questões teóricas, é importante envolver os resultados científicos de especialistas em diferentes direções: administração pública, filosofia, pedagogia, psicologia, sociologia, teoria da comunicação, estudos culturais, política, segurança nacional, economia. Determinou-se que as razões do nível insuficiente de prontidão dos professores para o trabalho sistemático e intencional na educação patriótica dos alunos devem ser buscadas no uso incompleto do potencial das disciplinas educacionais, na falta de métodos científicos e substantivos e em um conjunto de práticas didáticas, ferramentas (livros didáticos, audiolivros, materiais didáticos) que auxiliam na aquisição prática dos conhecimentos, habilidades e uso criativo dos alunos nas atividades cognitivas.
\end{abstract}

\section{Palavras-chave}

Reforma da educação. Educação patriótica nacional. Políticas públicas. Competências cívicas e sociais.

\section{Política estatal sobre la formación de las competencias cívicas y sociales de los estudiantes en condiciones de reforma educativa}

\begin{abstract}
Resumen
El artículo enfatiza la relevancia de la formación de las competencias cívicas y sociales de los estudiantes durante la reforma de las instituciones educativas de acuerdo con el concepto de la Nueva Escuela de Ucrania, con la capacidad de apreciar la diversidad cultural de los diferentes pueblos e identificarse como ciudadanos de Ucrania. Se hace hincapié en los resultados de la investigación y el trabajo experimental "Formación de la esfera de valor significativo de los niños en edad preescolar y primaria" sobre los temas de la educación patriótica nacional. Se propone considerar la idea nacional a través de la reflexión filosófica de los problemas educativos en las condiciones de la globalización e identificar las tendencias del desarrollo de la educación nacional en respuesta a los desafíos y riesgos de la sociedad moderna que afectan el funcionamiento de las instituciones educativas. Para resolver problemas teóricos, es importante involucrar los resultados científicos de especialistas en diferentes direcciones: administración pública, filosofía, pedagogía, psicología, sociología, teoría de la comunicación, estudios culturales, politología, seguridad nacional, economía. Se determina que las razones del nivel insuficiente de preparación de los docentes
\end{abstract}


para el trabajo sistemático y con propósito sobre la educación patriótica de los estudiantes deben buscarse en el uso incompleto del potencial de las materias educativas, la falta de métodos científicos y sustantivos y un conjunto de didácticas, herramientas (libros de texto, audiolibros, materiales didácticos) que brindan apoyo en la adquisición práctica de los conocimientos, habilidades y uso creativo de los estudiantes en la actividad cognitiva.

Palabras clave

Reforma educativa. Educación patriótica nacional. Política pública. Competencias cívicas y sociales.

\section{Introduction}

Problem statement. The Ukrainian state policy with its national idea is open to the integration of Ukrainian education into the European space. The National idea combining with Christian ethics and democratic values serve as a worldview for the younger generation of Ukrainians who respond to the national mentality and help to shape civic and social competences, including awareness of the ideas of democracy, justice, equality, human rights, well-being and healthy life, equal rights and opportunities, the ability to appreciate the cultural diversity of different peoples and identify themselves as citizens of Ukraine (New Ukrainian School. Concept aspects of secondary school reform, 2016).

Actual scientific researches and issues analysis. The issues of national idea research are devoted to the scientific development of well-known national scientists who claim:

[...] The philosophy of national idea contains all forms of reflection on the idea of nation [...] national idea is a synthetic view of one's own nation, ethnic community - as a circle defining the horizons of the world and self-determination, and at the same time as a subject of the world historical process. (GORSKY, 2001).

Popovich (2005) emphasizes:

[...] a national idea is a public project of a national scale, an integral part of which is a certain understanding of the objective status of a nation, its values and problems, as well as national goals and ways to achieve them. And a modern Ukrainian project is being constructed in an effort to form the Ukrainian national idea.

National identity is a component of national consciousness, which in turn, according to Shynkarenko et al. (2020), is a person's awareness of his or her own identity to a certain national group, which has its name, own historical territory, common myths, 
historical memory, common mass public culture, own language, common economy, all legal rights and obligations that are equal for all people.

Therefore, in order to understand the national idea (where its source is, where it is formed, how the national idea enters our self-perception), it is important to analyze the national idea through the philosophical reflection of the educational issues in the context of globalization and to identify the tendencies of developing national education in response to the challenges and risks of modern society which affect the functioning of educational institutions. And institutions, according to North (1997), these are the rules of the game in society, or, more formally, man-made restrictive frameworks that organize relationships between people. Thus, they set the structure of the motives for human interaction in politics, social sphere, economy (YANKOVYI et al., 2020). Institutional changes determine how societies evolve over time, and it is the key to understanding historical change.

Moreover, to solve theoretical issues it is relevant to involve the scientific results of specialists in different directions: public administration (process management, state security), philosophy (forming national consciousness), pedagogy (methodology and technology of pedagogical influence), psychology (problems of motivation and selfidentification), sociology (opinion survey), communication theory (media outreach), cultural studies (preserving national culture, traditions, tolerance and politics of multiculturalism), politology (preserving the state), national security (preserving social standards, defining social partners, developing social projects, considering requests for social justice), economy (determing priorities of budgetary and non-budgetary financing of educational institutions, involving cooperation of local self-government bodies, business structures and public organizations).

Education as a purposeful development of personality plays an important role in the socio-cultural process: it is a cultural experience of previous generations. At the same time, the role of the cultural function of education, which is determined by the goals of socialization of the person, grows, and at the same time it is supplemented by the formation of the individual's creative abilities, the transfer of spiritual values and certain social norms. The modern age is characterized by globalization processes in all spheres of our life, including education and upbringing. Educational institutions in the communicative space of modern culture seek to substantiate the philosophical foundations of 
contemporary education research, but Ukrainian scholars pay less attention to the issues of education, so scientific views on the educational problems are the purpose of this research.

The solution to the problem of education and upbringing is directly related to the individual's self-actualization through certain educational institutions (KVITKA et al., 2019; MUSHYNSKA, 2018). Today, in our globalized society, there is a growing contradiction between public needs for quality education and its real indicators (BUKANOV et al., 2019). A person lives, learns, is brought up in a society with certain cultural traditions. It is the object of philosophical research. Accordingly, the problem of education and upbringing of a man is today a socio-philosophical one and must be explored in connection with the development of modern culture under the influence of globalization processes. Classical philosophy of education explores the educational processes within the ethical and aesthetic aspects. The issues of norms, standards, educational ideal are revealed by the representatives of non-classical philosophical thought; hermeneutics interprets education in the context of the contents of the vital imperative. Modern philosophers, sociologists, educators consider education as a process, as a result, as technology, as didactic, and as a way of life. To be educated or not is every person's conscious choice nowadays. Which educational institution to choose for a child, where to improve our knowledge, what technologies, what standards are attractive to us and why? - Every person who ponders the meaning of life asks these questions. The problem of free choice and freedom belongs to one of the central ones regarding in philosophy, our daily lives and pedagogy, all the search for personality. This is stated in the work by Kultayeva. But in recent decades, the author emphasizes, there is an abuse of this concept, resulting in its loss of life, becoming an ideologem, and in the worst case - a corporate label thinking, trying to present itself in the marketplace of ideas as a modern and anti-totalitarian phenomenon. The researcher emphasizes that nowadays the calls for freedom, creativity and self-realization are the basis of pedagogical culture, but few scientists thought about the contents, conceptual values and conditions of its realization (KULTAEVA, 2009; MARTYNENKO; VOZNYUK, 2018).

How is this freedom enjoyed by modern educators, former graduates of pedagogical universities, when trying to solve complex issues not only on education but also on upbringing, including the national ones? Most of them are aware of the anthropological and humanistic approach to student preparation. And they should be 
among the most educated people in society. But today there is a catastrophic deterioration of education, despite some successfil results, and the reason for such deterioration can be explained by the aggravated interaction of education with negative factors of the cultural and social environment. And one of the ways to eliminate emerging contradictions is to form a culture of personality as a new strategy of optimizing the interaction with different environments of the existence, the basis of updating the modern system of educational institutions, and national-patriotic education, including what is emphasized in the works by Sahuichenko (2019a, 2019b).

Reforming educational institutions requires a theoretical justification for educational reform and broad support in society (SAHUICHENKO, 2019c). Therefore, the practical implementation of social competences introduced at the New Ukrainian School can be helped by the work on the project "Social Partnership as a Platform for Supporting Educational Reforms". The philosophy behind this project is to encourage all participants in the educational process to review their capacities, evaluate and identify the practical achievements that we today refer to social competences. They teach to identify the strengths and weaknesses of a school work which is provided according to the model suggested by John Dewey; identify needs during the learning process and solve problems in the local community; learn to work as a team, with other institutions and stakeholders on further collaboration; evaluate personal work with the local community; be able to identify general principles for school-based activities and services. In the future, it enables: to determine the level of development and priorities of future joint actions; to ensure that the entire community is involved in programs that address problems and meet needs; to involve parents in the decision-making process regarding the quality of education for their children and participation in school life. In today's complex society, we see that the school should not only focus on learning. To date, many students are involved in extracurricular activities. Therefore, one of the goals of the school is to create person-centered programs to improve learning in collaboration with local community partners. In a democratic society that is not the diversity of the totalitarian regime, issues of organization and management concern not only a narrow circle of leaders and specialists, but also all people who participate in joint organized or self-organized activities and are interested in achieving high productivity of their labor and creative efforts in a system of rationally organized work, built on a democratic and 
scientifically sound basis (DROBNIC, 2019; GVISHIANI, 1998; KOVAL; POLYEZHAYEV; BEZKHLIBNA, 2018). Given today's changes in management, delegation or partial redistribution will significantly reduce the pressure of school heads on the personality of students, educators, and parents, as we need to spread this authority to the extent that it relates to the interaction of the school with the parent community, to which community personally acquainted with one another, are able and capable of directly addressing their common problems, making full use of their parental potential (TOYNBEE, 1996). If today we are tasked with rebuilding the system, then in carrying out this task we must anticipate the emergence of a:

[...] new level of organization with qualitatively new structures and necessary new forms of management, focused on the choice of those strategies that would ensure the survival of the system. Since education as a subsystem of such megasystems as culture, economy, religion, politics and many others is not only self-organizing and self-improving, but also undergoes social management, it is necessary to take into account that it is the dynamics of correlation of internal and external regulators of its existence and development and determine what potential internally determined trends will be realized and will remain in the state of opportunity. A synergistic understanding of the role of these regulators warns against the following forms of their influence: bureaucratic, commanding, ideological, dogmatic and overly politicized. (YEVTODIUK, 2004).

This requires us to implement a culturally appropriate and humanly responsive synergistic management that would take into account the self-regulation of educational systems (BODNAR; MIRKOVICH; KOVAL, 2019). Therefore, in this context, the role of public self-government bodies, in particular parental self-government, in preventing voluntary violence against socio-cultural organizations is important, which include education systems (YEVTODIUK, 2004).

To date, the state policy of Ukraine in the field of national-patriotic education is implemented in accordance with the provisions of the Constitution of Ukraine and relevant regulatory legal documents.

The study of the patriotic upbringing of students in the educational process of institutions of general secondary education is revealed in the article by Shynkarenko "Formación remota del personal pedagógico en el sistema educativo de posgrado dentro del marco de la nueva escuela ucrania", in which he considers patriotism as an interconnected set of ethical feelings and behaviors, including love for the Motherland, active work for the good of the Motherland, maintaining and enhancing the traditions of

Educ. Form., Fortaleza, v. 5, n. 3, p. 1-22, set./dez. 2020

DOI: https://doi.org/10.25053/redufor.v5i15set/dez.3080

https://revistas.uece.br/index.php/redufor/index 
the people, caring for the historical monuments and customs of the native country (SHYNKARENKO et al., 2019).

Patriotism is one of the most important features of a well-developed personality. Students should gradually develop a sense of pride in their homeland and their Ukrainian people, respect and pride in its great achievements and victories of worthy pages of the past. Much depends on the modern school: its role in this difficult task cannot be overstated. The problem is that at present school patriotic education has almost come down, as they say, "to the point". Many factors have contributed to this over the last few years: the increased media coverage of the wrong path of Ukraine's development, the lack of a common state, so-called basic ideology. In addition, patriotic education is complicated by the lack of methodological literature in which teachers can find and use guidance and advice on the issue. If the teacher of general secondary education in everyday work begins to systematically refer to the materials of manuals on patriotic education, it will allow to grow a new generation of people of noble, convinced, ready to act for the benefit of Ukraine, those who are called the short word "patriot".

Practical work was focused on the themes "Formation of value and content sphere of preschool and young children" (state registration number 0118U 04952) and "Humanities education and personality: modern meaningful transformations for sustainable development" (state registration number 0118U004951).

\section{The objectives of the study are:}

1. identification of the initial level of patriotic upbringing of students in the conditions of educational reform;

2. substantiation of methods and techniques of diagnostics of students' patriotic education;

3. identification of teachers' level of preparedness for work on patriotic education of students;

4. generalization of the results of the study of the existing level of students' patriotic education;

5. theoretical substantiation of the need for the formation of students' civic and social competences during the reform of educational institutions. 


\section{Scientific findings}

In order to identify the initial level of patriotic upbringing of students in forms 2-11, a test experiment was conducted.

The ascertaining stage of the experiment was aimed at studying the state of the educational process of general secondary education institutions in terms of patriotic education. At this stage, the work experience of the general secondary education institutions in patriotic upbringing was analyzed, diagnostic methods were selected and implemented to study the level of patriotic upbringing of students in forms 2-11 of general secondary education institutions; conducted qualitative and quantitative analysis of the results obtained to identify the level of patriotism among students.

The experiment was conducted under the natural conditions of the educational process of general secondary education institutions, and some provisions of the work were checked among teachers, students, teachers-trainees of the advanced training of the Communal Institution of Higher Education "Dnipro Academy of Continuing Education" DRC.

Two groups of forms 2-6 and forms 7-11 were selected as the basis for the ascertainment experiment. A total of 45 teachers, 567 students participated in the experimental work, 281 of them were in the experimental group 1 and 286 were in the group 2.

The sample criteria were: approximately the same level of ideas about patriotism, their number in classes.

Four levels of patriotic upbringing by defined criteria and indicators (high, sufficient, medium, low) are presented (BEZENA, 2020; SHYNKARENKO, 2017).

$A$ high level is characterized by excellent knowledge of the history of Ukraine, the Ukrainian language, culture and traditions of the native people, respect for the historical past; responsible attitude to learning; understanding of the essence of patriotism, the presence of a clearly substantiated patriotic position, stable value orientations; able to assess the social situation in the country, the republic, etc. Pupils show patriotic and national aspirations in their own and social and public life, choice of work path, expressed a strong interest in the topic of patriotism. They understand the valuable national-patriotic attitudes and national-cultural experience of the people. Students at this level have a 
bright value-patriotic consciousness, intercultural tolerance, active subjective-patriotic attitude towards contemporary events. Students actively participate in the preparation and implementation of educational activities of patriotic content. They try to engage in self-education, to be useful to their country, to defend national independence.

A sufficient level is characterized by a deep understanding of the essence of patriotism, the presence of a clearly argued patriotic position, stable value orientations. The students show a strong interest in the topic of patriotism, have sufficient knowledge of the Ukrainian language, history of Ukraine, general education disciplines, and seek to improve and deepen this knowledge. Students at this level have a value-patriotic consciousness, intercultural tolerance, active subjective-patriotic attitude towards contemporary events. High school students take an active part in community activities and take initiative in patriotic selfimprovement. At this level, students have a systematic knowledge of patriotism within the curriculum, in some cases showing a need for self-education in the field.

A medium level is characterized by a combination of a clear patriotic position, patriotic values, perceptions, ideals, a sufficient level of knowledge of language, history, and culture. Pupils with a medium level of patriotic upbringing understand the valuable national-patriotic attitudes and national-cultural priorities; realize social problems but cannot specify national needs; occasionally display their patriotic duty and may not always satisfy their own labor interests. At this level, students have a systematic knowledge of patriotism within the curriculum, in some cases showing a need for selfeducation in the field. Knowledge of the Ukrainian language, history of Ukraine and general subjects is sufficient. Students are interested in the traditions, customs and culture of the Ukrainian people. The level of tolerance towards representatives of other nations is sufficiently developed. However, there is a superficial interest in everything Ukrainian, and the need to encourage patriotic orientation in the educational activities with the support of teachers or comrades.

A low level is characterized by passive attitude to the issues of patriotism, lack of a clear patriotic position, unformed value orientations, lack of intercultural tolerance, ignorance of the Ukrainian language, history of Ukraine, culture of its people, students, who are aware of this level, do not try to expand their knowledge of this phenomenon, they show indifferent attitude to the future of their homeland, which is manifested in irresponsible attitude to study, community responsibilities, lack of desire for self- 
education, patriotic feelings. Superficially they understand social problems and do not realize their patriotic duty to the state; they are not interested in productive work and are subject to group influence in choosing their own life priorities. The need for active patriotic activities is not expressed, there is no desire for self-education, and manifestation of patriotic feelings. Pupils are not self-motivated, they avoid participating in community service, patriotic activities. There are elements of alienation and indifference in the sociopolitical sphere. They are indifferent and sometimes negative about the culture, traditions, customs and history of their people. They do not adequately evaluate and respond to events that occur in the East of our country.

In the course of the ascertainment experiment, based on different approaches by educators and psychologists to determine the formation of students' patriotic upbringing, a system of indicators of the qualitative state of the main components of patriotism was developed. All these metrics are closely interrelated and interdependent. They can characterize several components of the patriotic upbringing of students: cognitive, emotional-motivational, activity-creative, ethno-identification.

To solve the objectives of the study and test the hypothesis of the study we used a set of general scientific and pedagogical methods, mutually verifying and complementary.

To diagnose the patriotic upbringing of students, the methods and techniques presented in tables 1,2 were used.

Table 1 - Methods and techniques for diagnosing the patriotic upbringing of students

\begin{tabular}{|c|c|c|}
\hline № & Criteria and indicators & Methods and techniques of the research work \\
\hline $\mathbf{1}$ & Value-patriotic outlook \\
\hline 1.1 & Patriotic outlook knowledge & Method of analysis \\
\hline 1.2 & Value-patriotic consciousness & Method "Value Orientations" \\
\hline 1.3 & Knowledge of native language & Results of writing test papers \\
\hline 1.4 & Understanding the legacy of famous artists & Observations; creative projects \\
\hline $\mathbf{2}$ & Patriotic-directed activity \\
\hline 2.1 & Interest & Conversation method \\
\hline 2.2 & Cognitive activity & Method of analysis; questionnaire \\
\hline 2.3 & Tolerant attitude towards different cultures & Method of analysis \\
\hline 2.4 & $\begin{array}{c}\text { Your own emotional attitude to the culture of } \\
\text { your native land }\end{array}$ & $\begin{array}{c}\text { Folk games, musical and folklore activities; peer } \\
\text { review method }\end{array}$ \\
\hline 2.5 & Willingness to defend the Homeland & Questionnaire; testing \\
\hline
\end{tabular}

Source: Own elaboration (2020).

Educ. Form., Fortaleza, v. 5, n. 3, p. 1-22, set./dez. 2020

DOI: https://doi.org/10.25053/redufor.v5i15set/dez.3080

https://revistas.uece.br/index.php/redufor/index 
The main theoretical methods were historical-bibliographic, comparative, systemic, logical, retrospective; method of modeling, generalization of experience.

Empirical methods included experimental methods - ascertaining and forming experiments, questioning, testing, observation, expert evaluation. At each stage, different methods of cognition were used, which made up a comprehensive methodology of research.

The complex of applied diagnostic methods (questioning, testing, interviews, creative tasks, various questionnaires) during the control sections should reveal one or another degree of manifestation of a certain indicator of patriotic upbringing of students. For this purpose, the corresponding criteria were measured on the basis of their manifestation in points (0-3 points). According to the total number of points for each of the indicators, the level of formation of the investigated quality was determined by this or that criterion.

Table 2 - Methods and techniques for diagnosing the patriotic upbringing of students

\begin{tabular}{|c|c|c|}
\hline № & Criteria and indicators & Methods and techniques of the research work \\
\hline 1 & \multicolumn{2}{|c|}{ Patriotic creative activity } \\
\hline 1.1 & $\begin{array}{l}\text { Participation in mastering the artistic heritage } \\
\text { of the native land }\end{array}$ & $\begin{array}{l}\text { Method of analysis; method of conversation; } \\
\text { questionnaire }\end{array}$ \\
\hline 1.2 & Capture the process of patriotic activity & Method of analysis; method of conversation \\
\hline 1.3 & Responsible attitude to learning & Questionnaire \\
\hline 1.4 & $\begin{array}{l}\text { Participation in the preparation and holding } \\
\text { of educational activities of patriotic content }\end{array}$ & Round tables \\
\hline 1.5 & $\begin{array}{c}\text { Students' desire to master the artistic and } \\
\text { musical values of the region }\end{array}$ & Observation; excursions \\
\hline 2 & \multicolumn{2}{|c|}{ Personification and cultural identification of personality } \\
\hline 2.1 & $\begin{array}{l}\text { Awareness of their involvement in the } \\
\text { Ukrainian ethnic group }\end{array}$ & Assessements; conversations; reflection \\
\hline 2.2 & $\begin{array}{l}\text { The need of the individual for certain forms } \\
\text { of group identification }\end{array}$ & Diagnostic techniques \\
\hline 2.3 & Respect for the historical past of the country & Virtual travels; meetings with veterans \\
\hline 2.4 & Self-determination in the Social Space & $\begin{array}{l}\text { Form periods; method of analysis; method of } \\
\text { conversation }\end{array}$ \\
\hline 2.5 & Knowledge of Ukrainian culture and traditions & Working with cards \\
\hline
\end{tabular}

Source: Own elaboration (2020).

Furthermore, we present the results obtained and their analysis. Interviews of students (567 people) and teachers (62 people) were conducted using the program (questionnaire) created in advance. The interviewees were staffed by school staff with a pedagogical background and the ability to easily communicate with the interlocutor, being easy and able to ask questions, manage the interview. Teachers and students interviewed followed the rules. First of all, the interview was conducted on its own with a participant without outsiders. Its duration should not exceed 20 minutes. Questions were 
asked from memory, and the interview had the spirit of a casual conversation. Responses were recorded during the interview in a notebook as short notes, which were then transcribed and recorded in a standard questionnaire.

The questionnaires were compiled with the modern requirements. Particular attention during the preparation of the questionnaires addressed the formulation of questions that, for the sake of their unambiguous understanding, the students were subjected to primary standardization, and also tested the simplicity and accessibility of their subsequent processing.

Test tasks were developed and applied to find out the level of patriotic knowledge of the students. Here is the main content of the questions.

1. Discover what content you put into the concept of "patriotism".

2. Name the people who you think could serve as a model patriot.

3. What are the actions of the students you would refer to as "patriotic".

4. Name the books you read in the last year outlining the patriots of your country.

5. Which of these musical instruments are Ukrainian folk?

6. Which of these songs is Ukrainian folk? (SHYNKARENKO, 2018).

At this stage of our study, 295 students in forms 2-6 and 272 students in forms 711 participated. The survey revealed the students' attitude towards their homeland and understanding of the basic concepts of patriotic content. Among students in forms 2-6 and forms 7-11, answering "Who is a patriot?" $13.5 \%$ said these were people who were living in Ukraine, $15.7 \%$ said that they were people who loved the Motherland, 23,3\% said theye were people who defended their country; $13.3 \%$ thought these wete people who were not indifferent to the fate of the country; $12.6 \%$ said they were people working for the benefit of Ukraine, $17.4 \%$ thought they were are people who were experiencing all the problems with Ukraine. $4.2 \%$ were undecided. The results of the study showed that there were some students who identified the concept of Motherland and the state, which brings a certain contradiction in their views.

When asked, "Discover what content you put into the concept of "patriotism"' and "What, in your opinion, manifests such a phenomenon as 'patriotism", it revealed that students did not fully have a common understanding of the concept of patriotism. In particular, more than $85.1 \%$ did not reveal the general characteristic of this concept.

Educ. Form., Fortaleza, v. 5, n. 3, p. 1-22, set./dez. 2020 
We were also interested in how students understood the concept "Motherland". It turned out that $15.1 \%$ of the students were convinced that "the Motherland is the place where you live and fulfill your responsibilities"; $10.3 \%$ of them understood it as "home"; $15.4 \%$ - as "native land"; $15.3 \%$ - as "the land of my people"; $13.4 \%$ of the students thought "it is the place of birth"; $10.3 \%$ considered "it is a place where parents and relatives live", $3.2 \%$ considered "it is a place where you study", $17 \%$ thought "it is my home land".

When asked, "Name the people who you think could serve as a model patriot" $47.1 \%$ of students answered meaningfully.

Somewhat difficult for the students was the question "What are the actions of the students you would refer to as 'patriotic'?". A substantial answer to this question was given by $32.8 \%$ of students.

The following question helped us identify how students in forms 2-6 and forms 711 saw their future. The answers were distributed as follows:

$24.6 \%$ dreamt of graduating from high school, entering higher education, having a good profession; $10.1 \%$ wanted to live in harmony; $57.6 \%$ wanted to leave Ukraine; $2.1 \%$ did not want to think; $3.3 \%$ associated their future with military service; $2.3 \%$ believed that people would live without a job and a salary.

The generalized results of the study of the existing level of patriotic upbringing of students are given in Table 3 and 4.

Qualitative data analysis Table 3 and 4 indicate the advantage of medium and low levels of patriotic upbringing of students according to all the studied criteria.

Table 3 - Summary table of the results of the ascertaining study of the students' patriotic educatedness, in \%

\begin{tabular}{|c|c|c|c|c|c|c|c|c|c|c|}
\hline & \multicolumn{10}{|c|}{ Levels of performing indicators of patriotic educatedness } \\
\hline & \multicolumn{4}{|c|}{ EG } & \multirow{2}{*}{ 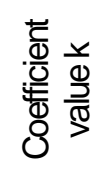 } & \multicolumn{4}{|c|}{ CG } & \multirow{2}{*}{ 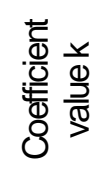 } \\
\hline & High & $\begin{array}{c}\text { Suffici } \\
\text { ent }\end{array}$ & Medium & Low & & High & $\begin{array}{c}\text { Suffici } \\
\text { ent }\end{array}$ & Medium & Low & \\
\hline Co & 10,7 & 17,7 & 25,6 & 46,0 & 0,43 & 11,7 & 19,0 & 28,6 & 40,7 & 0,42 \\
\hline $\mathrm{Ca}$ & 9,7 & 15,5 & 28,0 & 46,8 & 0,72 & 10,3 & 13,6 & 28,5 & 47,6 & 0,73 \\
\hline Cca & 13,9 & 21,9 & 28,6 & 35,6 & 0,71 & 13,7 & 22,0 & 28,9 & 35,4 & 0,70 \\
\hline $\mathrm{Cp}$ & 11,8 & 16,3 & 25,2 & 46,7 & 0,47 & 13,1 & 18,3 & 27,8 & 40,8 & 0,49 \\
\hline Média & 11,5 & 17,9 & 26,8 & 43,8 & 0,58 & 12,2 & 18,2 & 28,5 & 41,1 & 0,59 \\
\hline
\end{tabular}

Source: Own elaboration (2020).

Educ. Form., Fortaleza, v. 5, n. 3, p. 1-22, set./dez. 2020

DOI: https://doi.org/10.25053/redufor.v5i15set/dez.3080

https://revistas.uece.br/index.php/redufor/index 
Table 4 - The results of the ascertaining study of the formation of the criteria of students' patriotic educatiedness

\begin{tabular}{c|c|c|c|c}
\hline \multirow{2}{*}{ Criterion } & \multicolumn{2}{c|}{ Coefficient of formation } & \multicolumn{2}{c}{ Level of formation } \\
\cline { 2 - 5 } & Group 1 & Group 2 & Group 1 & Group 2 \\
\hline Value-patriotic activity & 0,72 & 0,73 & Medium & Medium \\
\hline Patriotic-directed activity & 0,71 & 0,70 & Medium & Medium \\
\hline Value-patriotic outlook & 0,43 & 0,42 & Low & Low \\
\hline $\begin{array}{c}\text { Personification and cultural identity of the } \\
\text { individual }\end{array}$ & 0,47 & 0,49 & Low & Low \\
\hline Average amount & $\mathbf{0 , 5 8}$ & $\mathbf{0 , 5 9}$ & Low & Low \\
\hline
\end{tabular}

Source: Own elaboration (2020).

As we can see, the students' levels on the criteria of personification and cultural identity (coefficients are 0.47 for students of experimental and 0.59 for students of control groups) and value-patriotic outlook ( 0.43 and 0.42 respectively) are low.

Comparing the data with the characteristics of the levels of students' patriotic educatedness, we found out the initial level of formation of the studied quality (see Table 5).

Table 5 - The initial level of students' patriotic educatedness, in \%

\begin{tabular}{c|c|c|c|c}
\hline Groups & High & Sufficient & Medium & Low \\
\hline Group 1 & 11,5 & 17,9 & 26,8 & 43,8 \\
\hline Group 2 & 12,2 & 18,2 & 28,5 & 41,1 \\
\hline
\end{tabular}

Source: Own elaboration (2020).

For visual (qualitative) comparison of patriotic educatedness of students in group 1 and group 2, we present the results of the study using a compatible histogram.

Figure 1 - Dynamics of levels of patriotic educatedness of students of group 1 and group 2 before the forming experiment

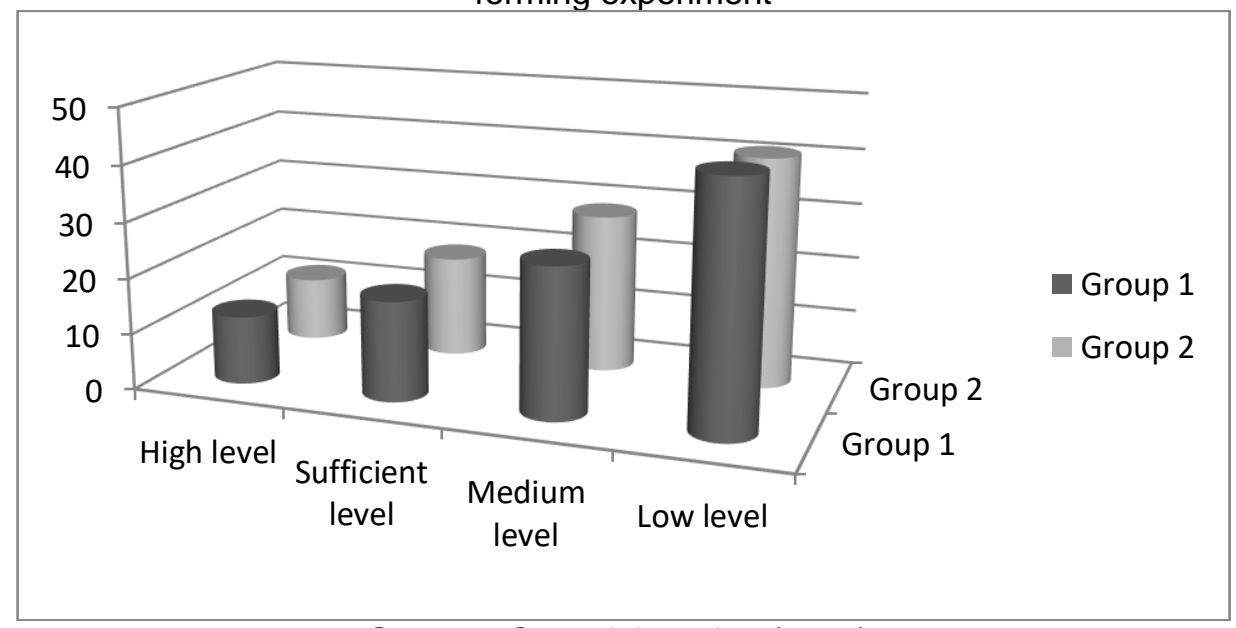

Source: Own elaboration (2020).

Educ. Form., Fortaleza, v. 5, n. 3, p. 1-22, set./dez. 2020

DOI: https://doi.org/10.25053/redufor.v5i15set/dez.3080

https://revistas.uece.br/index.php/redufor/index 
The results show that the majority of students in both control and experimental groups have low levels of patriotic educatedness (ranging from $40 \%$ to $50 \%$ ), only about $20 \%$ of the students show a high level.

We prove using the methods of mathematical statistics that are chosen group 1 and group 2 did not differ in their prior to the experiment characteristics of patriotic educatedness.

On the basis of the data in Table 4, we will test the reliability of the hypothesis regarding the absence, from a statistical point of view, of differences between the levels of patriotic upbringing of students of group 1 and group 2. For this purpose we use Pearson's $x 2$ criterion. The calculation will be made by the formula:

$$
\chi_{\text {eun }}^{2}=\frac{1}{n_{1} n_{2}} \sum_{i=0}^{C-1} \frac{\left(n_{1} Q_{2 i}-n_{2} Q_{1 i}\right)^{2}}{Q_{1 i}+Q_{2 i}}
$$

where, $Q_{1 i}$ i $Q_{2 i}$ - number of students in control and experimental groups, respectively, belonging to one or another level of patriotic education;

$n_{1}, n_{2}-$ the number of students from relevant groups;

$C$ - the number of categories studied, that is, levels of patriotic upbringing, $C=4$.

$X^{2}$ емп $=0,18$, for $X^{2}$ крит $=0,11$. That is, $99 \%$ is likely to indicate that there are no differences between group 1 students and group 2 students at the beginning of the experiment.

In order to find out the reasons for the low level of patriotic upbringing of students, the existing factors of the educational process of general secondary education institutions were examined.

The findings show that there is a discrepancy between the growing influence of the media on the process of formimg an individual and the use of these opportunities in school practice. The modern student is influenced by the media, but they are spontaneously affected. Often this impact is negative. Deprived of the opportunity to visit cultural centers and even to read newspapers and magazines, today's student is forced to meet the violence, death, and violence that filled the TV screens dozens of times a night. This causes the student to become accustomed to evil as a norm, to stop responding to it. It has been noted among students that there is a steady increase in dissatisfaction with politicians and policies that can turn into active rejection of them into political extremism. This 
perspective is quite possible, because it is based on the psychological characteristics of students: youthful maximalism, the desire to quickly solve problems, intolerance.

One way out is to increase the orientation of the teacher on the selectivity of students while choosing the necessary information, the development of students' culture of perception, the ability to correctly evaluate the necessary information. The teacher himself must also be prepared to facilitate the proper assessment of the events of the surrounding life, to help choose the main thing that would contribute to the development of personality, the upbringing of patriotism.

So it turned out that almost all schools where the experiment had been conducted had no extracurricular work on patriotic education. Not all the lessons were delivered with information technology tools, although there was an opportunity, it was noticed that the teachers almost did not use local studies.

Therefore, the level of preparedness of teachers of general secondary education institutions for patriotic education was presented.

To identify the level of teachers' readiness to work on the patriotic upbringing of students, testing was conducted to determine the level of teachers' civic and patriotic competences.

Thus, $7 \%$ of respondents believe that "Every nation has its customs developed over several years", $6 \%$ - "many centuries", $12 \%$ - "one century". These figures reflect the low percentage of teachers who are oriented in some of the characteristics of patriotic education. As for the element of social and cultural heritage that is passed on to future generations and preserved for a long time in society, $37.2 \%$ of teachers have identified as the tradition. True answers were received from $28 \%$ of respondents.

The results obtained indicate that the understanding of the essence of patriotic education by the majority of teachers is unclear, which negatively affects the process of its upbringing.

The study found that out of 52 teachers, only $18 \%$ were prepared to work systematically on patriotic education; $18.1 \%$ of them consider age and individual characteristics during patriotic education; $14.7 \%$ use cross-curricular lessons; $11.4 \%$ use information technology tools. Most teachers (78\%) use forms of work such as reading paragraphs at a lesson, dictation reading, which undoubtedly do not cause students cognitive interest in the study of patriotic education. 


\section{Conclusions and directions for future research}

The reasons for teachers' lack of preparedness for systematic and purposeful work on students' patriotic upbringing should be sought in the incomplete use of the potential of the teaching subjects, the lack of methods and a set of didactic tools (textbooks, tutorials, audiobooks, audio aids, in the practical mastery of students' folk knowledge, skills and their creative use in cognitive activity.

This gives reason to consider as the main mission to solve complex issues of education and nurture the formation of perception of the world as a whole, where the well-being of each is directly dependent on the well-being of others. All institutions of the education system consider that their main function is to create optimal conditions for the adequate adaptation of the individual to certain socio-cultural realities that have developed in a particular society. The content of education depends on the ideas, needs, ideals that exist in a certain socio-cultural space. This content is aimed at supporting the existing foundations, while creating a certain abstract illustration of a representative of society. The principle of selecting information from the accumulated cultural layer in accordance with specific social needs becomes relevant.

Today, more than ever, true informatization of society requires extensive professional training. But at the same time it is not possible to continue to postpone the materials that are included into the accumulated great achievements of traditional culture. There is also a conflict between the modern and the traditional, between "Our" and "the Other". The various structures of society, that are supposed to be educational institutions, try to find the approaches and ways of resolving this conflict. Kindergartens, schools, colleges, universities, institutes of postgraduate pedagogical education, out-of-school educational institutions, regardless of ownership, are not indifferent to this difficult issue. The role of public organizations that are concerned about the current state of modern education and upbringing is growing. It is difficult to underestimate the role of the state, its power structures: only in the last year or two in the legal documents attention is paid not only to education, but also emphasizes the role of education, including family, civic, patriotic, legal, pedagogy and media-pedagogy. 
All this indicates the growing indifference to the issue raised. Politics, economics, informatization, media culture, state security are also educational space (MUSIENKO, 2012; NECHAEV, 2004; SARRACIN, 2012).

\section{References}

BEZENA, I. Contemporary State Ethnocultural Policy: Organizations Implemented at the Regional Level in Democratization and Decentralization Processes in Ukraine, v. 69, p. 30-37, 2020.

BODNAR, S.; MIRKOVICH, I.; KOVAL, V. Human capital development in Ukrainian education system by means of language integrated teaching. Dilemas Contemporáneos: Educación Política y Valores, Toluca, v. 7, n. 14, 2019.

BUKANOV, $\mathrm{H}$. et al. Social marketing in public administration of social service institutions. Revista Gênero \& Direito, João Pessoa, v. 8, n. 6, p. 457-468, 2019.

DROBNIC, J. The Key Innovations in Career Guidance on Labour Market. Economics, Ecology, Socium, v. 3, n. 1, p. 12-22, 2019.

GORSKY, V. Philosophy in Ukrainian culture. Methodology and History, v. 1, p. 37-39, 2001.

GVISHIANI, D. Organization and management: monograph. Moscow: Bauman's MSTU, 13-15, 1998.

KOVAL, V.; POLYEZHAYEV, Y.; BEZKHLIBNA, A. Communicative competences in enhancing of regional competitiveness in the labour market. Baltic Journal of Economic Studies, v. 4, n. 5, p. 105-113, 2018.

KULTAEVA, M. Philosophical and anthropological substantiation of the culture of freedom and its educational implications: theoretical experience of modern German philosophical thought, n. 8, p. 80-98, 2009.

KVITKA, S. et al. Marketing of Ukrainian higher educational institutions representation based on modeling of Webometrics Ranking. Marketing and Management of Innovations, v. 3, p. 60-72, 2019.

MARTYNENKO, O.; VOZNYUK, L. Features of management of innovative processes in the conditions of reforming school education. New Pedagogical Thought, v. 1, p. 12-16, 2018. 
MUSHYNSKA, N. Means of future economists' professional self-development in the educational process of foreign language studying. Economics, Ecology, Socium, v. 2, n. 3, p. 45-56, 2018.

MUSIENKO, I. Educational strategies for shaping national interests in the age of globalization, v. 9, p. 117-121, 2012.

NECHAEV, V. Globalization parameters and factors of the Bologna process. Bulletin of the Moscow University, v. 4, v. 27-34, 2004.

NORTH, D. Institutions, institutional change and economic performance. New York: Cambridge University, 1997.

POPOVICH, M. Ukrainian national idea. Bulletin of the National Academy of Sciences of Ukraine, v. 8, p. 14-20, 2005.

SAHUICHENKO, V. Communication in education: reforms and risks. Dilemas Contemporáneos: Educación, Política y Valores, Toluca, v. 2, n. 1, p. 1-14, 2019a.

SAHUICHENKO, V. Postgraduate pedagogical education: trends andrisks. Dilemas Contemporáneos: Educación, Política y Valores, Toluca, v. 1, $2019 \mathrm{~b}$.

SAHUICHENKO, V. Theoretical and methodological substantiation of the reform of educational institutions. Sumy: PF University Book Publishing House, 2019c.

SARRACIN, T. Germany: Self-liquidation. (TA Nabatnikov, Transl.), p. 12-17, 2012.

SHYNKARENKO, V. Information technologies as a means of patriotic upbringing of students in the educational process of secondary schools. Physical and mathematical Education: a scientific journal, v. 2, n. 12, p. 174-177, 2017.

SHYNKARENKO, V. Structural-functional model of patriotic upbringing of high school students in the educational process of secondary schools. Innovative Pedagogy, v. 3, p. 272-275, 2018.

SHYNKARENKO, V. et al. Educational potential of and communication technologies in patriotic education of students. Revista Práxis Educacional, Vitória da Conquista, v. 16, n. 37, p. 539-552, 2020. DOI: 10.22481/praxisedu.v16i37.6404.

SHYNKARENKO, V. et al. Formación remota del personal pedagógico en el sistema educativo de posgrado dentro del marco de la nueva escuela ucrania. Dilemas Contemporáneos: Educación, Política y Valores, Toluca, v. 7, v. 65, 2019.

THIS is the Ukrainian School. Conceptual principles of secondary school reform. 2016. Ministry of Education and Science of Ukraine. 
TOYNBEE, A. D. Civilization before the court of history. Moscow: Progress Culture, 1996. v. 2.

YANKOVYI, O. et al. Economic assessment of investment on the basis of production functions. Turismo: Estudos \& Práticas, Mossoró, v. 2, p. 1-11, 2020.

YEVTODIUK, A. V. Synergistic-futurological dimension of modern philosophy of education. Practical Philosophy, v. 3, p. 218-228, 2004.
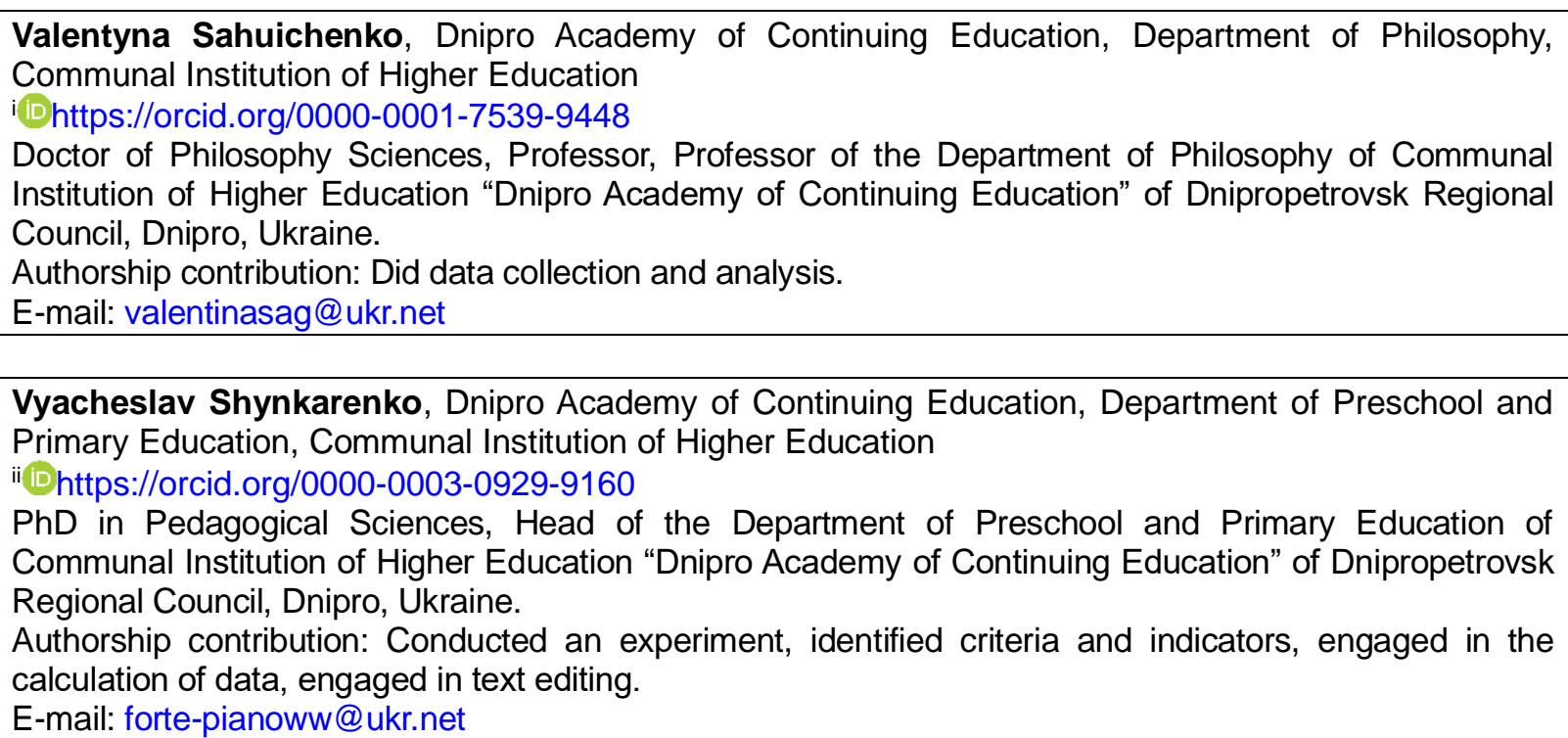

Ivan Bezena, Dnipro Academy of Continuing Education, Department of Social and Humanitarian Education, Communal Institution of Higher Education

iii-10https://orcid.org/0000-0002-7169-2038

PhD in Pedagogical Sciences, Associate Professor of the Department of Preschool and Primary Education of Communal Institution of Higher Education "Dnipro Academy of Continuing Education" of Dnipropetrovsk Regional Council, Dnipro, Ukraine.

Authorship contribution: Translated the article.

E-mail: ivan.bezen@ukr.net

Olha Perederii, Dnipro Academy of Continuing Education, Department of Preschool and Primary Education, Communal Institution of Higher Education

iv (1D https://orcid.org/0000-0002-1923-6780

$\mathrm{PhD}$ in Pedagogical Sciences, Associate Professor of the Department of Preschool and Primary Education of Communal Institution of Higher Education "Dnipro Academy of Continuing Education" of Dnipropetrovsk Regional Council, Dnipro, Ukraine.

Authorship contribution: Decorated chart tables.

E-mail: olgadnepr.1502@gmail.com

Educ. Form., Fortaleza, v. 5, n. 3, p. 1-22, set./dez. 2020

DOI: https://doi.org/10.25053/redufor.v5i15set/dez.3080

https://revistas.uece.br/index.php/redufor/index 
Olha Martynenko, Dnipro Academy of Continuing Education, Department of Educational Management, Public Policy and Economics, Communal Institution of Higher Education

$\checkmark$ (ID https://orcid.org/0000-0002-0827-0342

$\mathrm{PhD}$ in Economics, Head of the Department of Educational Management, Public Policy and Economics of Communal Institution of Higher Education "Dnipro Academy of Continuing Education" of Dnipropetrovsk Regional Council, Dnipro, Ukraine.

Authorship contribution: Participated in analysis and data collection.

E-mail: olga.stesenko@ukr.net

Responsible publisher: Lia Machado Fiuza Fialho Ad hoc experts: Cristine Brandenburg and Karla Angélica Silva do Nascimento

\section{How to cite this article (ABNT):}

SAHUICHENKO, Valentyna et al. State policy on the formation of students' civic and social competences in conditions of educational reform. Educ. Form., Fortaleza, v. 5, n. 3, p. 1-22, 2020. Available at:

https://revistas.uece.br/index.php/redufor/article/view/3080.

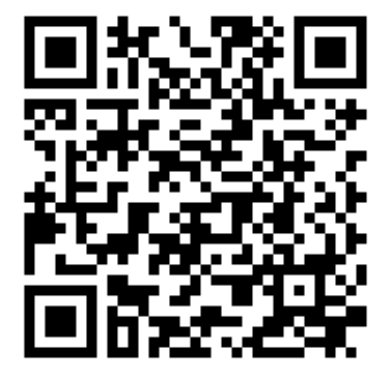

Received on May $4^{\text {th }}, 2020$.

Accepted on May $28^{\text {th }}, 2020$.

Published on June $30^{\text {th }}, 2020$. 